\title{
Exploration of bioactive compounds and antibacterial activity of marine blue-green microalgae (Oscillatoria sp.) isolated from coastal region of west Malaysia
}

\author{
Prakash Bhuyar ${ }^{1,2} \cdot$ Mohd Hasbi Ab. Rahim $^{1} \cdot$ Gaanty Pragas Maniam ${ }^{1} \cdot$ Rameshprabu Ramaraj $^{2} \cdot$ \\ Natanamurugaraj Govindan ${ }^{1}$
}

Received: 9 May 2020 / Accepted: 13 October 2020 / Published online: 27 October 2020

(c) Springer Nature Switzerland AG 2020

\begin{abstract}
Cyanobacteria is blue-green microalgae that produces a variety of secondary metabolites such as antibiotic, cytotoxic and antimicrobial agents. Present investigation proposed to study an extraction of active agents from Cyanobacteria and its antibacterial activity. The Cyanobacteria were collected, and isolated colony was found to be Oscillatoria sp. and it was grown in BG 11 medium for mass cultivation. Then the centrifuged biomass was weighed and used for extraction of bioactive compounds. GCMS analysis from Oscillatoria sp. determines fatty acid, triazine derivatives, pyridine derivatives, acridine derivatives. The result revealed that Oscillatoria sp. can play crucial roles as antibacterial agents because the methanolic extract are inhibiting the growth of $S$. aureus for gram-positive whereas $P$. aeruginosa for gram-negative bacteria. The crude extract was effective against $S$. aureus with the highest concentration, $100 \mathrm{mg} / \mathrm{ml}$ where area of the zone was $14.10 \pm 0.8 \mathrm{~mm}$. The crude extract actively inhibited $P$. aeruginosa at 75 and $100 \mathrm{mg} / \mathrm{ml}$ with highest area of inhibition were in the average of $13.23 \pm 0.1$ and $15.43 \pm 0.2 \mathrm{~mm}$. Finally, the antimicrobial activity was carried out by disc diffusion method with different concentrations of active compounds shows the MIC value in gram-positive bacteria was $30 \mu \mathrm{g} / \mathrm{ml}$ whereas for gram-negative bacteria was $25 \mu \mathrm{g} / \mathrm{ml}$. Cyanobacteria extract should be preferred and considered to be new natural drug or antibiotics in pharmaceutical and health care industry. This coastal region should be studied further by researchers to study more information and benefits in the future.
\end{abstract}

Keywords Oscillatoria sp. GCMS · MIC · Pathogen

\section{Introduction}

Microalgae are the photosynthetic organisms found in littoral habitats and throughout the ocean waters known as phytoplankton. Phytoplankton include such as diatoms (Bacillariophyta), Dinoflagellates (Dinophyta), green, yellow brown flagellates, and cyanobacteria (blue-green algae) [1-3]. Cyanobacteria is an incredible old group of prokaryotic organisms that produces a variety of secondary metabolites such as antibiotic, cytotoxic, immunosuppressive and enzyme inhibiting agents [4-6]. Bioactive compounds are defined as the secondary metabolites that can be isolated and purified from the microalgae, plant, microbes and other organisms that has ability in biological activities [7]. The production of bioactive compounds from microalgae can be beneficial in pharmaceutical industry $[8,9]$. Algae also contain several bioactive compounds that are beneficial as antimicrobial agent like terpenoids, steroid, phenolic compounds, alkenes and pholorotannins $[10,11]$.

\footnotetext{
$\triangle$ Natanamurugaraj Govindan, natanam@ump.edu.my | ${ }^{1}$ Algae Biotechnology Laboratory, Faculty of Industrial Sciences and Technology, Universiti Malaysia Pahang, Lebuhraya Tun Razak, 26300 Gambang, Kuantan, Pahang, Malaysia. ${ }^{2}$ School of Renewable Energy, Maejo University, Chiang Mai 50290, Thailand.
} 
Microalgae contain variety compounds that can react to inhibit the microbes like bacteria and function as antibacterial agent. This antibacterial agent can be found in variety of natural sources like in animal, plant and microalgae. Marine algae contribute to the biomass production in marine environment and they can also produce a variety of chemically active metabolite compounds to protect themselves against other microorganisms in their surrounding environment [10,12]. The marine microalgae are one of the main focuses to new function as the antimicrobial agents.

In this research, the marine microalgae were cultured in BG 11 medium. The antibiotics like Streptomycin, Penicillin and Vancomycin were supplemented in culture media to avoid or reduce the growth of the undesired microbes that will disturb the growth of the marine microalgae $[6$, $13,14]$. The aim of the study is to focus on the isolation of extract form of Oscillatoria sp. that possesses various biological active compounds which may play crucial roles as antibacterial agents against various type of gram-positive (S. aureus and $B$. subtilis) and gram-negative ( $P$. aeruginosa and E. coli) pathogenic bacteria. Moreover, the statistical data was determined by applying one-way ANOVA using Statistical Program for Social Sciences (SPSS) 16.0 software.

\section{Materials and methods}

\subsection{Sample collection followed by identification}

The sample collection was done at the Kuantan (3.812601103.372003.3 $48^{\prime} 45.36^{\prime \prime} \mathrm{N}, 103^{\circ} 22^{\prime} 19.21^{\prime \prime}$ E) costal region of east coast of west Malaysia. The sampling was done in the month of august in 2019. The marine water samples were collected with microalgae by plankton net and brought to laboratory. Serial dilution was carried out to get isolated colonies. The $\mathrm{pH}$ value of the medium was adjusted to $\mathrm{pH}$ 7.5 and the temperature was maintained at room temperature $25^{\circ} \mathrm{C} \pm 2{ }^{\circ} \mathrm{C}[15]$. The sample was observed and identified by using fluorescent microscope. The morphological observations and referred to Algae manual it confirmed that algae belong to blue-green algae group as shown in Fig. 1. The cell diameter is $3.6-4.8 \mu \mathrm{m}$ and the cell length is 1.2-1.8 $\mu \mathrm{m}$. Algae cell trichome aggregation was solitary with the granulated of cell [16]. According to algae manual the sample was confirmed that belong to Oscillatoria sp.

\subsection{Microalgae mass cultivation}

The single colony of cyanobacteria was cultured into $10 \mathrm{ml}$ BG 11 medium. After that, it was transferred into $250 \mathrm{ml}$ medium and adjusted to $500 \mathrm{ml}$ for mass culture. Cyanobacteria was cultivated in 2-L Erlenmeyer's flask contained BG-11 medium and incubated in the racks sourced with fluorescent lamps as a light source. The photo-incubation was carried out at $30^{\circ} \mathrm{C}$ and with illuminated at light intensities $12 \mathrm{~h}$ dark period measured by LI- 250 Light meter [17].

\subsection{Culturing of pathogenic bacteria}

The sterile inoculation loop was dipped in the bacterial suspension and the loopful of suspension streaked over the surface of the nutrient agar to obtain uniform growth. A final sweep was made around the rim of agar. The culture

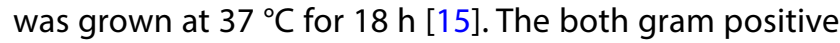
and gram-negative pathogenic bacteria were used for the study. The gram-negative bacteria used were $S$. aureus (CP019117) and B. subtilis (AL009126); and gram-positive

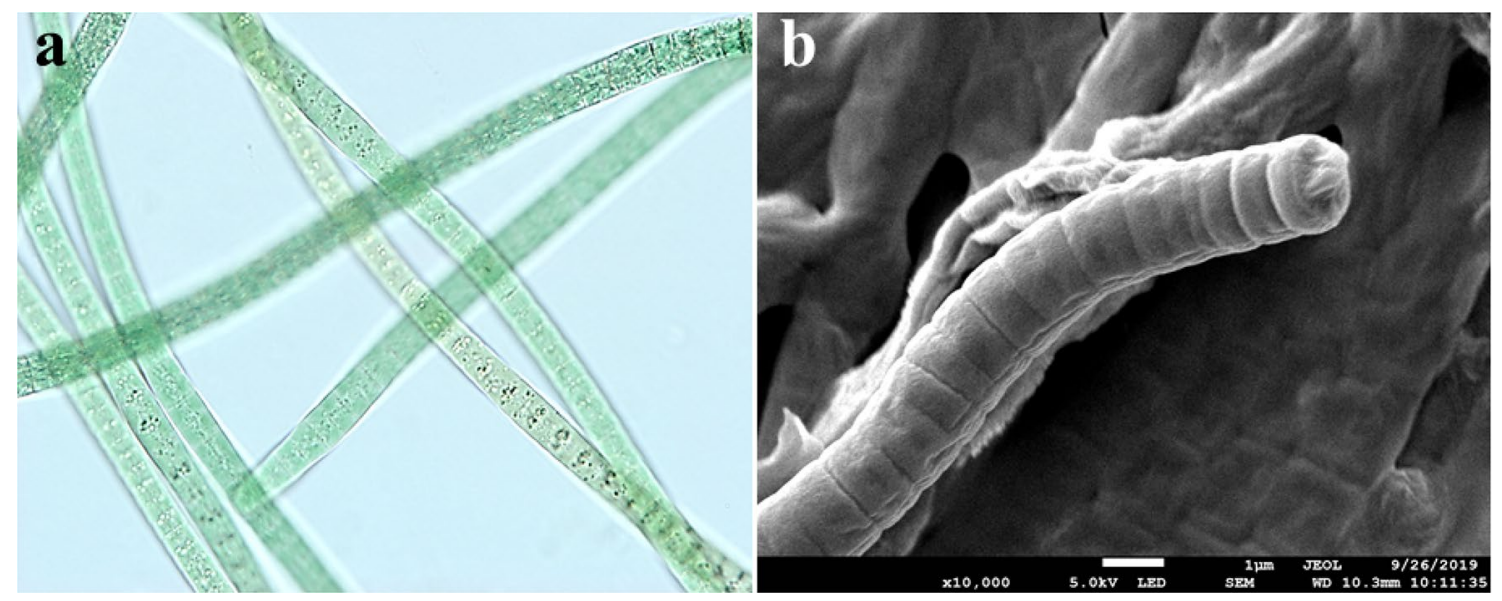

Fig. 1 Species of microalgae cyanobacteria Oscillatoria sp. a fluorescent microscopic images and b scanning electron microscope photograph 
bacteria used for the antimicrobial study were $E$. coli (U00096) and P. aeruginosa (PAO1).

\subsection{Preparation of crude extract of microalgae}

Algal mass culturing using BG II medium were separated from centrifugation at $5000 \mathrm{rpm}$ for $15 \mathrm{~min}$ and their pellets were dried at $60{ }^{\circ} \mathrm{C}$ for $24 \mathrm{~h}$. The dry algal mass was dissolved in methanol (ratio $1: 15 \mathrm{~g} / \mathrm{ml}$ ) and extracted throughout $24 \mathrm{~h}$ [18]. The supernatant was collected after being centrifuged at $10,000 \mathrm{rpm}$ for $10 \mathrm{~min}$. The solvent extracts were concentrated under reduced pressure at $40{ }^{\circ} \mathrm{C}$. The dried extracts were resuspended in $3 \mathrm{ml}$ of solvent with different concentration $(50,75$ and $100 \mathrm{mg} / \mathrm{ml})$ and preserved at $4{ }^{\circ} \mathrm{C}$ till further use in antimicrobial assays $[6,19]$.

\subsection{Antibacterial activity}

The antimicrobial activity was measured and determined using a well diffusion test [15]. The antibiotic $50 \mu$ of Streptomycin was used in this test as the control. The disks $(6 \mathrm{~mm})$ containing $30 \mu \mathrm{g} / \mathrm{ml}$ the extract form of the Oscillatoria sp. were placed on the surface of agar. The flame sterile forceps were used to dispense the antibiotic and extract disk one at a time. The distribution of the disks should be apart from each other and not close to the edge of plate. The bacteria inoculum was swabbed and inoculated on the media plates. The inoculated plates were then incubated for $24 \mathrm{~h}$ at $37^{\circ} \mathrm{C}$ and zone of inhibition was measured in millimeter $(\mathrm{mm})$ [20].

\subsection{Minimum inhibitory concentration (MIC)}

The 96 well microtiter plates were swept with ethanol before used. After that, the first row of well was pipetted with $50 \mu \mathrm{l}$ methanol as positive control, second row of well was pipetted with $50 \mu \mathrm{l}$ of nutrient broth and $50 \mu \mathrm{l}$ bacteria culture as negative control. Third row until seventh rows were filled with different concentration of sample in the range of $10,15,20,25$ and $30 \mu \mathrm{g} / \mathrm{ml}$ mixed with $50 \mu \mathrm{l}$ bacteria culture each. After leaving for $24 \mathrm{~h}$, the sample was analyzed with micro plate reader (TECAN, INFINITE M200PRO). The minimum inhibition concentration value was determined as the lowest concentration of the extract in the broth medium that inhibit the visible growth of the test microorganism [21].

\subsection{Gas-chromatography with mass spectrometer analysis}

The bioactive compounds present in the extracts of the Oscillatoria sp. which played important roles in the antimicrobial activity was measured and determined using the Gas Chromatography-Mass Spectroscopy [22]. The chromatographic column used HP-5 column ( $30 \mathrm{~m} \times 0.25 \mathrm{~mm}$ ID $\times 0.25 \mu \mathrm{m}$ film thickness), Agilent Technologies 7890A (GC system) model. The Chromatographic conditions were follows: The one micro liter of algae extract was injected into the GC-MS with Helium carrier gas and was maintained at a flow rate of $1.50 \mathrm{ml} / \mathrm{min}$; injector and column oven temperature of $280 \times$ and $80^{\circ} \mathrm{C}$; injection mode 'split' and split ratio 20:1. Oven temperature was held isothermal at $80^{\circ} \mathrm{C}$ for $1 \mathrm{~min}$, then increased to $300{ }^{\circ} \mathrm{C}$ at a rate of $4{ }^{\circ} \mathrm{C} / \mathrm{min}$ and held isothermal for $5 \mathrm{~min}$. MS, (Agilent Technologies $5975 \mathrm{C}$ model) conditions were followed: ion source temperature of $200^{\circ} \mathrm{C}$; interface temperature of $300^{\circ} \mathrm{C}$; mass range of $40-1000$ mass units $[17,23]$. The individual peaks formed were identified by comparing their retention time, as well as their mass spectra with the Fienn. Library and NIST 11 (National Institute of Standard and Technology, Gaithersburg, United States) library.

\subsection{Statistical analysis}

The result obtained from the experiment was statistically analyzed by applying one-way ANOVA with Turkey's Test by using SPSS 16.0 (Statistical Program Social Sciences) software.

\section{Results and discussion}

\subsection{Antibacterial activity}

Data and results for the zone of inhibition of crude extract of cyanobacteria against 4 different types of bacteria were illustrated in Table 1. The sample of crude extract of Oscillatoria sp. was tested with three different concentrations which were 50,75 and $100 \mathrm{mg} / \mathrm{ml}$. The streptomycin was used as the control for this inhibition. Each reading was taken as three replicates. The two different gram-positive bacteria (S. aureus and B. subtilis) and 2 type of gram-negative bacteria ( $E$. coli and $P$. aeruginosa) had shown slightly different area of inhibition when reacted with different concentration of extract from Oscillatoria sp. The antibacterial activity of microalgae was usually assayed using various organic solvent for effective extraction of biological active compounds. The commonly used organic solvent were methanol, acetone, ether and chloroform-methanol [24]. Most of all indicated that the methanol extraction yielded more compared to hexane and ethyl acetate.[7, 25, 26]. Ethyl acetate and methanol were determined as the most effective organic solvent for the isolation of antibacterial compounds $[27,28]$. 
Table 1 Zone of inhibition of Oscillatoria sp. against $S$. aureus, B. subtilis, E. coli, P. aeruginosa

\begin{tabular}{lcrrr}
\hline Microbe & \multicolumn{3}{l}{ Zone of inhibition $(\mathrm{mm})$} \\
\cline { 2 - 5 } & $\begin{array}{l}\text { Streptomycin con- } \\
\text { trol }(\mathrm{mm})\end{array}$ & \multicolumn{2}{l}{ Concentration microalgae extract } \\
\cline { 3 - 5 } & & $50 \mathrm{mg} / \mathrm{ml}$ & $75 \mathrm{mg} / \mathrm{ml}$ & $100 \mathrm{mg} / \mathrm{ml}$ \\
\hline Staphylococcus aureus & $7.13 \pm 0.9$ & $4.23 \pm 0.2$ & $10.77 \pm 0.7$ & $14.10 \pm 0.8$ \\
Bacillus subtilis & $9.0 \pm 0.3$ & $3.17 \pm 0.4$ & $8.40 \pm 0.5$ & $9.10 \pm 0.7$ \\
Escherichia coli & $11.0 \pm 0.2$ & $3.03 \pm 0.8$ & $9.26 \pm 0.6$ & $10.17 \pm 0.4$ \\
Pseudomonas aeruginosa & $9.0 \pm 0.5$ & $7.50 \pm 0.1$ & $13.23 \pm 0.1$ & $15.43 \pm 0.2$ \\
\hline
\end{tabular}

\subsubsection{Zone of inhibition of Staphylococcus aureus}

Table 1 indicated the result for zone of inhibition when crude extract of Oscillatoria sp. reacted with gram-positive bacteria S. aureus. The crude extract was effective against S. aureus with the highest concentration, $100 \mathrm{mg} / \mathrm{ml}$ where area of the zone was $14.10 \pm 0.8 \mathrm{~mm}$. However, for concentration $50 \mathrm{mg} / \mathrm{ml}$, there was still inhibition, but it was slightly lower, only in the average of $4.23 \pm 0.2 \mathrm{~mm}$. The methanolic extract of microalgae show antibacterial activity inhibited in the $S$. aureus with maximum zone of inhibition of $12 \mathrm{~mm}$ at the concentration of $0.2 \mathrm{mg} / \mathrm{ml}$ [29]. The zone of inhibition produced in reaction of methanol extract of Oscillatoria sp. with $2 \mathrm{mg} /$ disk in S. aureus was $27 \mathrm{~mm}$ [14]. The most sensitive gram-positive bacteria to the methanolic extract of Oscillatoria sp. was $\mathrm{S}$. aureus with the zone of inhibition of $13.8 \pm 0.8 \mathrm{~mm}$ [28].

The area for zone of inhibition increases as the concentration of cyanobacteria extract increases. The extract of
Oscillatoria sp. was most effectively in the inhibited growth of S. aureus with high concentration of $100 \mathrm{mg} / \mathrm{ml}$ (Fig. 2).

\subsubsection{Zone of inhibition of Bacillus subtilis}

The zone of inhibition for the reaction of crude extract of Oscillatoria sp. against $B$. subtilis was indicated as in Table 1 . The crude extract was actively inhibited $B$. subtilis at 75 and $100 \mathrm{mg} / \mathrm{ml}$ with the highest area of inhibition, $9.10 \pm 0.7 \mathrm{~mm}$. Other concentration of $50 \mathrm{mg} / \mathrm{ml}$ zone of inhibition was only in average $3.17 \pm 0.4 \mathrm{~mm}$. The maximum zone of inhibition of methanol extract of marine microalgae with $2 \mathrm{mg} /$ disk in against $B$. subtilis was $22 \mathrm{~mm}$ [14]. The previous study by [27] proved similar result for the zone of inhibition of microalgae against $B$. subtilis.

In Fig. 2, shows the area for zone of inhibition of crude extract of Oscillatoria sp. against $B$. subtilis which was active with the concentration $100 \mathrm{mg} / \mathrm{ml}$ which almost close to the zone of inhibition produced by Streptomycin
Fig. 2 Zone inhibition for a Staphylococcus aureus b Escherichia coli c $P$. aeruginosa d B. subtilis
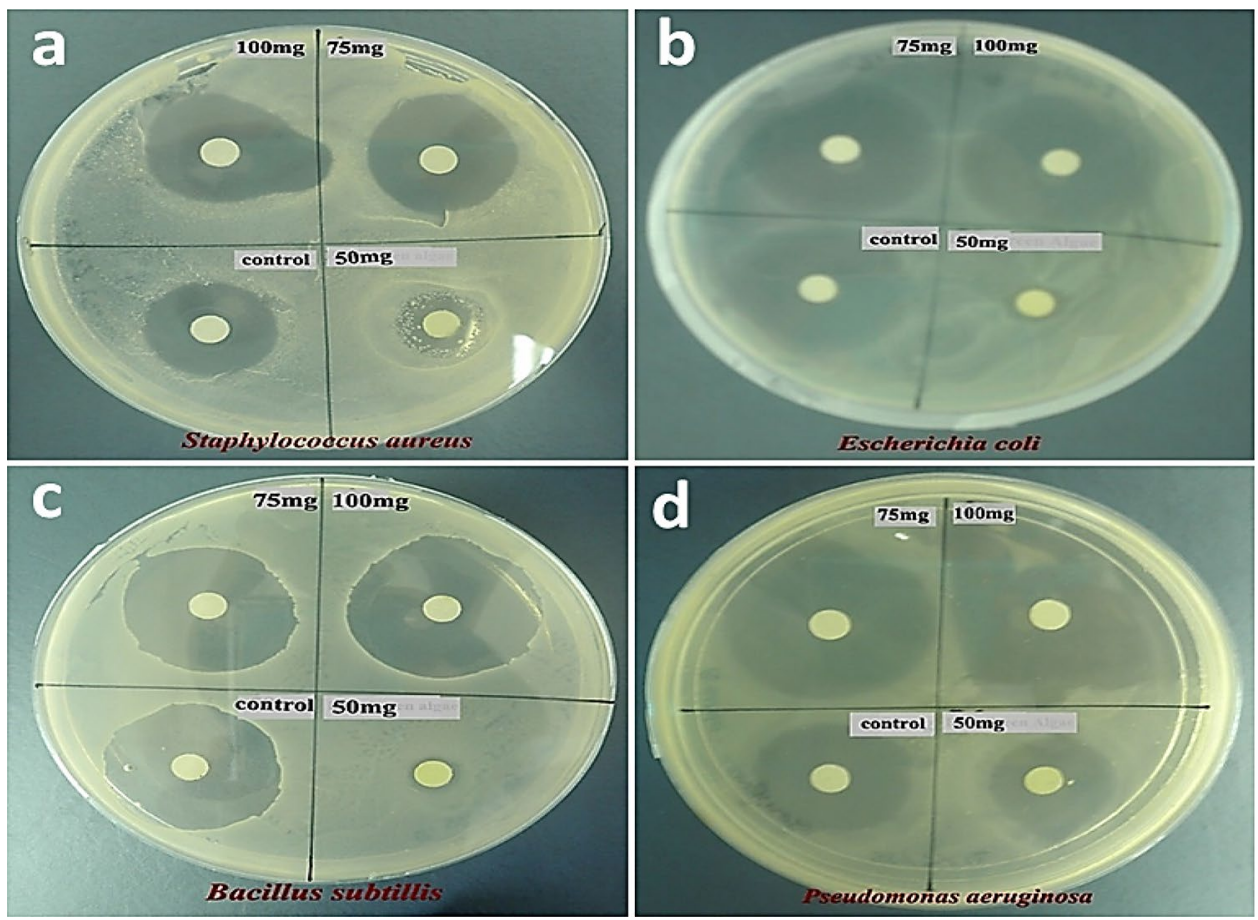
(control). Besides $100 \mathrm{mg} / \mathrm{ml}$, the concentration of $75 \mathrm{mg} / \mathrm{ml}$ also produced large zone of inhibition whereas the $50 \mathrm{mg} / \mathrm{ml}$ concentration showed the lowest activity against $B$. subtilis.

\subsubsection{Zone of inhibition of Escherichia coli}

Based on Table 1, it states that the crude extract of Oscillatoria sp. was highly responsible in inhibiting E.coli at the concentration of $100 \mathrm{mg} / \mathrm{ml}$ with area of inhibition was $10.17 \pm 0.4 \mathrm{~mm}$ whereas for concentration $50 \mathrm{mg} /$ $\mathrm{ml}$, the area of inhibition was quite low which was only $3.03 \pm 0.8 \mathrm{~mm}$. The zone of inhibition from this experiment was similar with the previous study by Salem et al. [28] who reported the zone of inhibition of $E$. coli when treated with methanolic extract of microalgae form area of inhibition in the range of $8 \pm 1-13.3 \pm 1.2 \mathrm{~mm}$. However, in previous study of Anandhan et al. [27] it shows that the zone of inhibition of methanolic extract of microalgae inhibited $E$. coli was $12 \mathrm{~mm}$. The zone of inhibition reported by Rebecca et al. [30] was $20 \mathrm{~mm}$ for $100 \mathrm{mg} / \mathrm{ml}$ and $15 \mathrm{~mm}$ for $50 \mathrm{mg} / \mathrm{ml}$.

In Fig. 2, shows the increasing zone of inhibition against E. coli as the concentration of Oscillatoria sp. extract increased. The 75 and $100 \mathrm{mg} / \mathrm{ml}$ slightly produced the same area for zone of inhibition and effective inhibited growth of $E$. coli whereas the $50 \mathrm{mg} / \mathrm{ml}$ concentration proved the lowest antibacterial activity against $E$. coli.

\subsubsection{Zone of inhibition of Pseudomonas aeruginosa}

The zone of inhibition for reaction of crude extract of Oscillatoria sp. in against $P$. aeruginosa was indicated in Table 1. The crude extract actively inhibited $P$. aeruginos $a$ at $75 \mathrm{mg} /$ $\mathrm{ml}$ and $100 \mathrm{mg} / \mathrm{ml}$ with highest area of inhibition were in the average of $13.23 \pm 0.1 \mathrm{~mm}$ and $15.43 \pm 0.2 \mathrm{~mm}$. For the concentration of $50 \mathrm{mg} / \mathrm{ml}$, the area of zone of inhibition was slightly high in average $7.50 \pm 0.1 \mathrm{~mm}$. The most gram-negative bacteria that was sensitive to methanolic extract of microalgae were $P$. aeruginos $a$ with the zone of inhibition was $15 \pm 1 \mathrm{~mm}$ [28]. The zone of inhibition of methanol extract of microalgae inhibited in $P$. aeruginosa obtained from this experiment was similar to the experiment done by Anandhan et al. [27].

Based on Fig. 2, the graph shows that the $100 \mathrm{mg} /$ $\mathrm{ml}$ was the most active concentration of Oscillatoria sp. extract that can inhibit growth of $P$. aeruginosa with larger zone of inhibition compared to Streptomycin that act as control. However, concentration at $50 \mathrm{mg} / \mathrm{ml}$ showed the lowest zone of inhibition compare to other concentration.

For concentration of $50 \mathrm{mg} / \mathrm{ml}$, the crude extract produced more efficiency to inhibit the $P$. aeruginosa with area of zone inhibition is $7.50 \pm 0.1 \mathrm{~mm}$ and less efficiency in inhibiting the $B$. subtilis and E. coli with zone of inhibition was $3.03 \pm 0.8 \mathrm{~mm}$ respectively as shown in Fig. 2 . The crude extract with $75 \mathrm{mg} / \mathrm{ml}$ concentration was also more effective against $P$. aeruginos $a$ and $S$. aureus with the reading of $13.23 \pm 0.1 \mathrm{~mm}$ and $10.77 \pm 0.7 \mathrm{~mm}$ respectively and less effective against $B$. subtilis where the area of inhibition was $8.40 \pm 0.5 \mathrm{~mm}$ as shown in Fig. 2. The crude extract of Oscillatoria sp. with concentration $100 \mathrm{mg} / \mathrm{ml}$ showed high antibacterial activity against the gram-negative bacteria that was $P$. aeruginosa which area of zone of inhibition was $15.43 \pm 0.2 \mathrm{~mm}$ as shown in Fig. 2 whereas shows less antibacterial activity against the gram-positive bacteria that was B. subtilis which area of inhibition was $9.10 \pm 0.7 \mathrm{~mm}$.

The similar study reported by Arnab Pramanik and Joydeep Mukherjee [6] have revealed the Phormidium sp. strongly acted as antibacterial agent against the $P$. aeruginosa with $14 \mathrm{~mm}$ zone of inhibition. The LPP group $B$ showed the effectiveness in inhibiting the $S$. aureus $(18 \mathrm{~mm})$, B. subtilis $(15 \mathrm{~mm})$ and E. coli $(15 \mathrm{~mm})$.

The microalgae extract was mostly active in gram negative bacteria compared to gram positive [28]. Previous studies indicated that the methanol extraction yielded more compared to hexane and ethyl acetate $[25,31]$. In the previous report of Rao et al. and Rajasulochana et al. [32], they revealed similar investigation as in this experiment where the active compounds in the extract of microalgae was active against $S$. aureus for gram-positive bacteria and P. aeruginosa for gram-negative bacteria. Oscillatoria sp. proved the antibacterial activity against gram-negative and gram-positive bacteria [33].

\subsection{Minimum inhibitory concentration (MIC)}

\subsubsection{Gram-negative bacteria: Pseudomonas aeruginosa}

The results from 96-well micro titer plate analyzed by micro titer plate reader. The positive control is the solvent namely methanol that was used to extract the bioactive compound from the crude extract of the Oscillatoria sp. The negative control used was the culture of selected bacteria with the nutrient broth. The different concentrations of Oscillatoria sp. extract were prepared from 10, 15, 20, 25 and $30 \mu \mathrm{g} / \mathrm{ml}$ (Fig. 3). From the data, the reading is slightly in ascending form of the inhibition level that occurred in the micro plate between reactions of Oscillatoria sp. extract against the bacteria culture. The pattern of inhibition level formed can be seen more clearly from the graphical data.

Figure 3 shows the level of inhibition produced from the reaction of crude extract from Oscillatoria sp. against the bacteria Pseudomonas aeruginosa. From the graph, it shows the increasing level of inhibition. The most minimal concentration that can cause this inhibition to occur 


\section{Minimal Inhibitory Concentration}

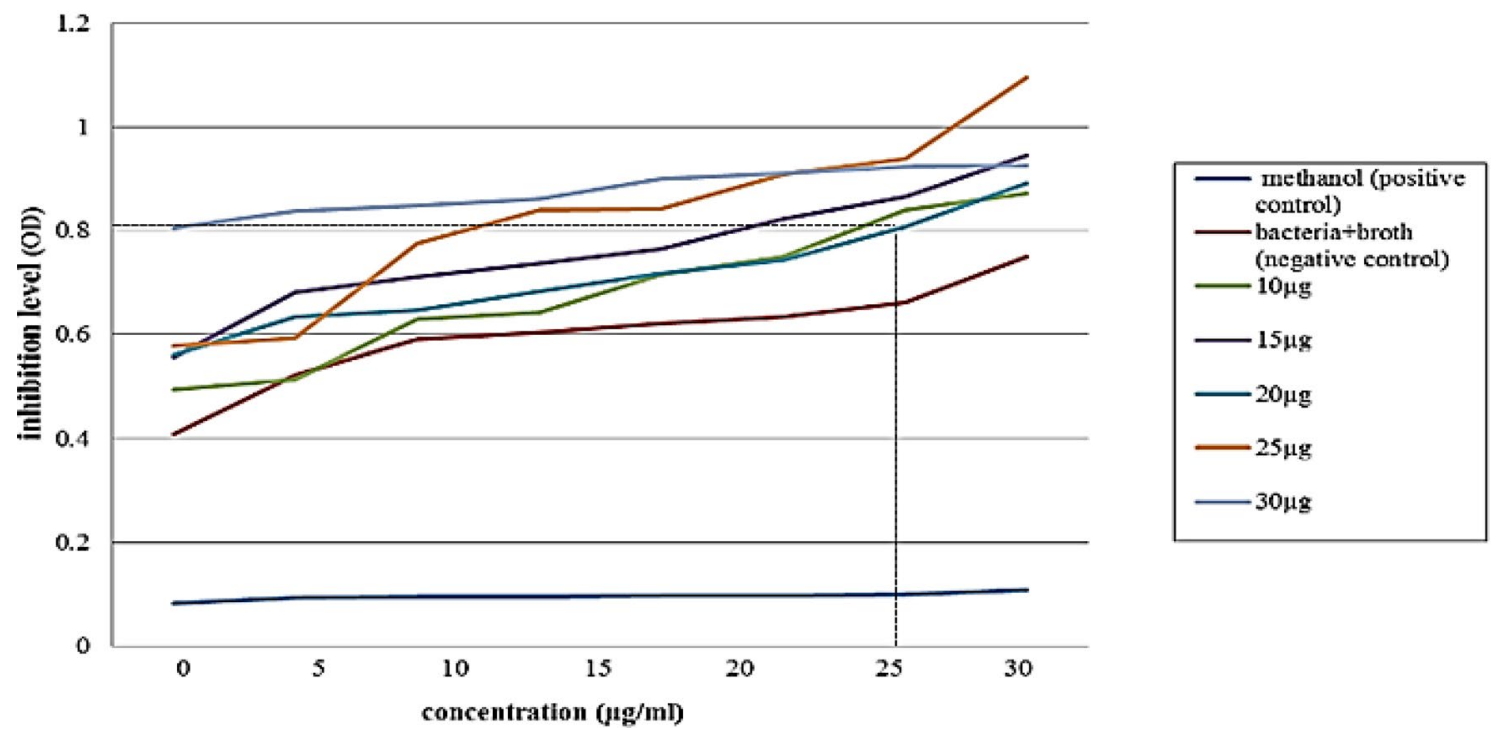

Fig. 3 Graph of level of inhibition (OD) against concentration of sample for minimal inhibitory concentration (MIC) for P. aeruginosa

effectively is $25 \mu \mathrm{g} / \mathrm{ml}$ with the optimal density is 0.9391 . The Oscillatoria sp. extract depends on $25 \mu \mathrm{g} / \mathrm{ml}$ to control the growth of gram-negative bacteria $P$. aeruginosa because the active compounds which function to inhibit growth of bacteria was active in this concentration.

Besides that, the graph also shows that the inhibition level for each concentration started to increase at the concentration $5 \mu \mathrm{g} / \mathrm{ml}$. So, it shows that at the concentration of $25 \mu \mathrm{g} / \mathrm{ml}$ the antibacterial activity of crude extract from Oscillatoria sp. against the gram-negative bacteria, P. aeruginosa is higher. The MIC result obtained from this experiment was almost the same as the previous study by [28] Salem et al. where the MIC for P. aeruginosa was $20 \mu \mathrm{g} / \mathrm{ml}$.

\subsubsection{Gram-positive bacteria: Staphylococcus aureus}

Figure 4 indicates the data analyzed by the micro titer plate reader from the reaction of the gram-positive bacteria that is $S$. aureus with different concentration of crude extract of Oscillatoria sp. The different concentration prepared were $10,15,20,25$ and $30 \mu \mathrm{g} / \mathrm{ml}$.

The solvent methanol was used as the positive control whereas the selected bacteria culture within nutrient broth was served as negative control. The reading of level of inhibition produce was ascending for each concentration. The graphical data may present clear pattern produced from that reaction.

Figure 4 above presents the increasing reading pattern for the level of inhibition produced from the reaction of crude extract of Oscillatoria sp. in inhibiting the grampositive bacteria S. aureus. The different concentration of crude extract from Oscillatoria sp. studied in this experiment were 10, 15, 20, 25 and $30 \mu \mathrm{g} / \mathrm{ml}$. Hence, from the graph above the minimal concentration that may inhibit the reaction of bacteria was $30 \mu \mathrm{g} / \mathrm{ml}$ with the level of optimum density was 0.4764 . It proved that at concentration of $30 \mu \mathrm{g} / \mathrm{ml}$, the crude extract of Oscillatoria sp. can function as antibacterial agent efficiently against the gram-positive bacteria S. aureus. The minimal inhibitory concentration (MIC) for microalgae against $S$. aureus was $25 \mu \mathrm{g} / \mathrm{ml}$ because the di-phenolic metabolites like bromophenols were found to be the most effective compound as antimicrobial agents [34, 35].

The minimum inhibitory concentration (MIC) of marine algae against $S$. aureus was $0.5 \mathrm{mg} / \mathrm{ml}$ and maximum MIC was $1 \mathrm{mg} / \mathrm{ml}$. (Selim, 2012). The MIC for S. aureus obtained in this experiment was almost the same as the previous study of Salem et al. (2011) which was in the range of 20-50 $\mu \mathrm{g} / \mathrm{ml}$.

\subsection{Statistical analysis}

Figure 5 shows the antibacterial activity of Oscillatoria sp. extract with different concentrations (50,75 and $100 \mathrm{mg} /$ $\mathrm{ml}$ ) in 2 different types of gram-positive bacteria (S. aureus and B. subtilis) and 2 different types of gram-negative bacteria ( $E$. coli and $P$. aeruginosa). Therefore, the antibiotic Streptomycin was served as control. The result showed a significantly higher antibacterial activity $(p<0.05)$ which was determined by a one-way ANOVA and the error bars were by $S E M, n=3$. 


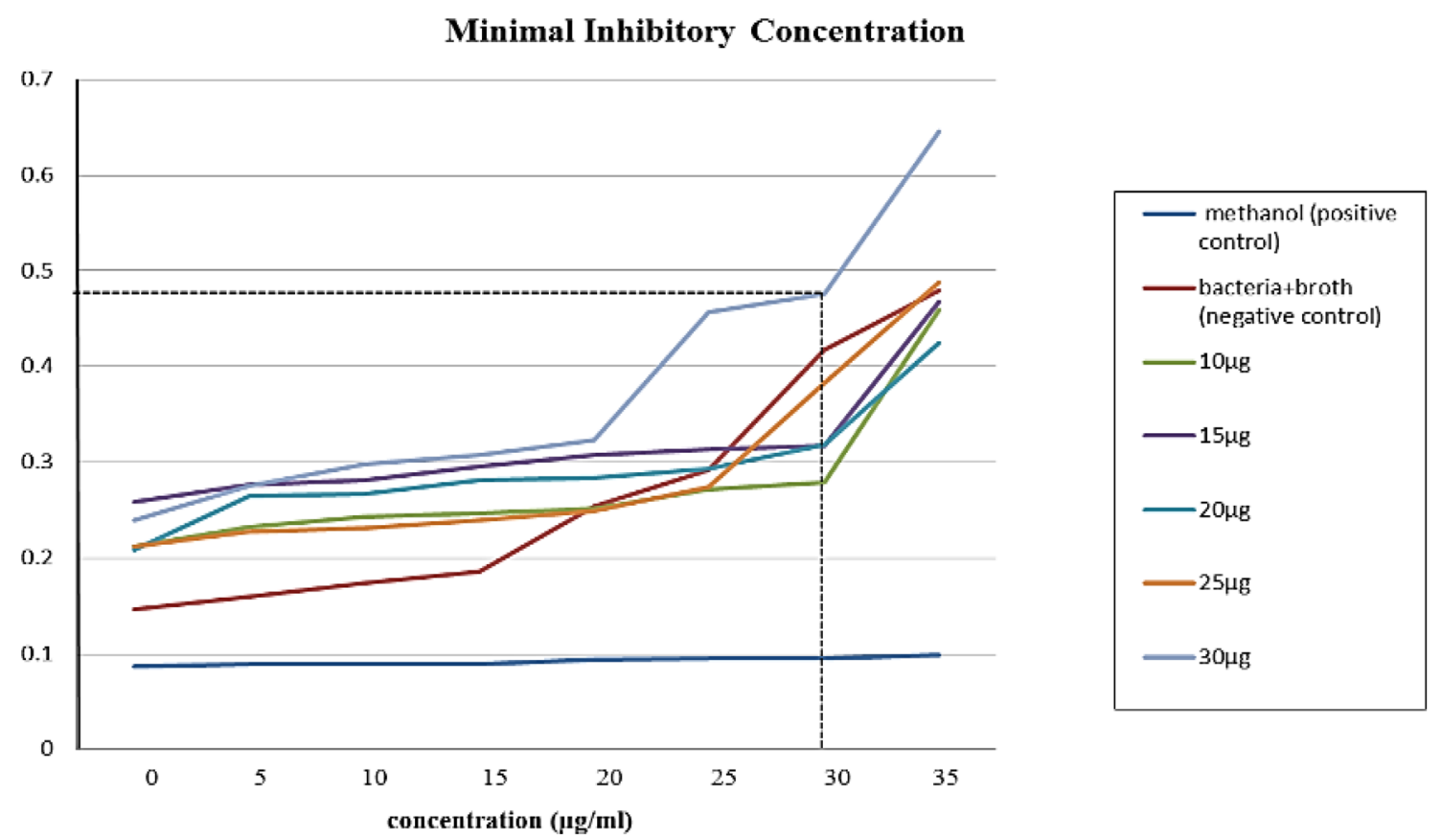

Fig. 4 Graph of level of inhibition (OD) against concentration of sample for minimal inhibitory concentration (MIC) for against S. aureus

Fig. 5 Antibacterial activity of Oscillatoria sp. extract with different concentrations $(50,75$ and $100 \mathrm{mg} / \mathrm{ml}$ )

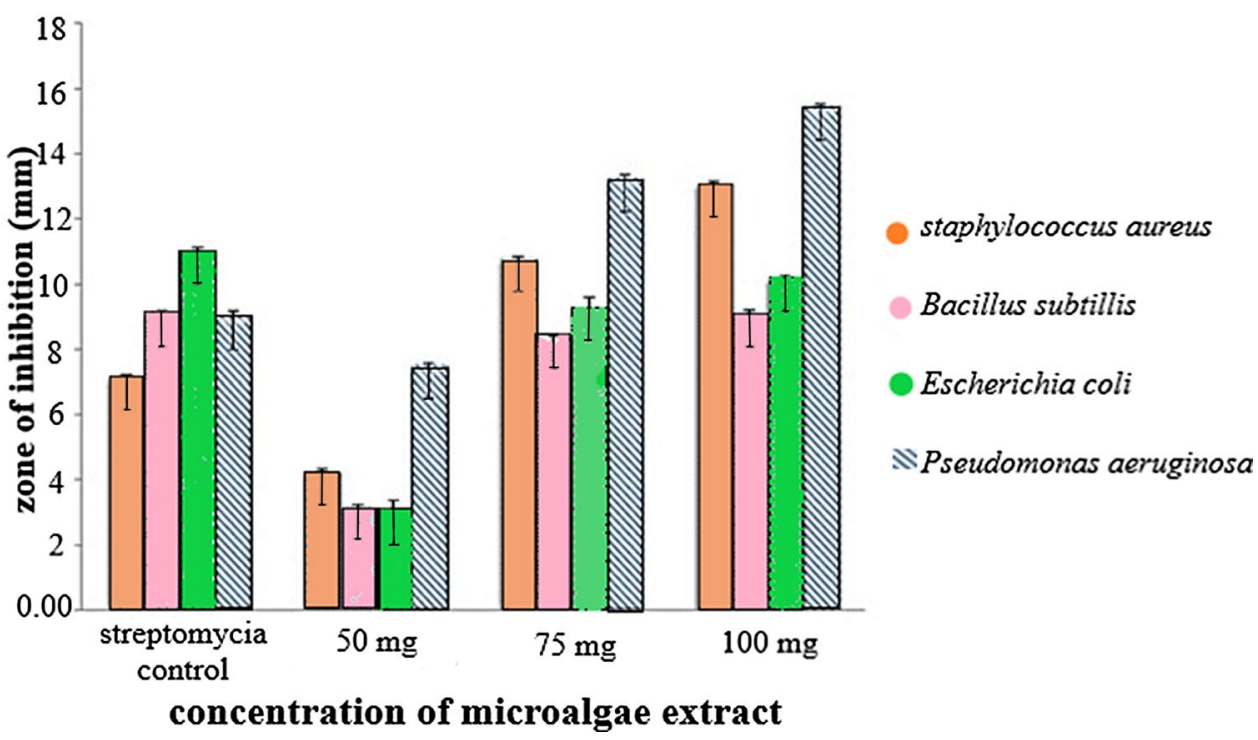

\subsection{Bioactive compounds analysis of cyanobacteria extract}

The bioactive compound identified in cyanobacteria were fatty acid, amino acid derivative, indolizine derivative, ether derivative, cinchoninic acid, phenol, pyridine derivative, benzyl alcohol derivative and triazine derivative as shown in Fig. 6 and Table 2. Halogenated compounds present in microalgae and macroalgae were indicated as biological active compounds [36, 37]. The important compounds that were indicated as antimicrobial are fatty acid, acrylic acid, terpenes, phenol and halogenated compounds [29]. Previous study by Kolanjinathan et al. [20] found the most bioactive compounds that present in microalgae extract was chemically classified as aromatics, sulphate polysaccharide, brominated, nitrogen-heterocyclic, protein, peptides, dibutanoids, nitrosulphuric-heterocyclic and sterols. The Oscillatoria sp. was active against pathogenic bacteria with the presence of pyridine and n-butanol [33]. 


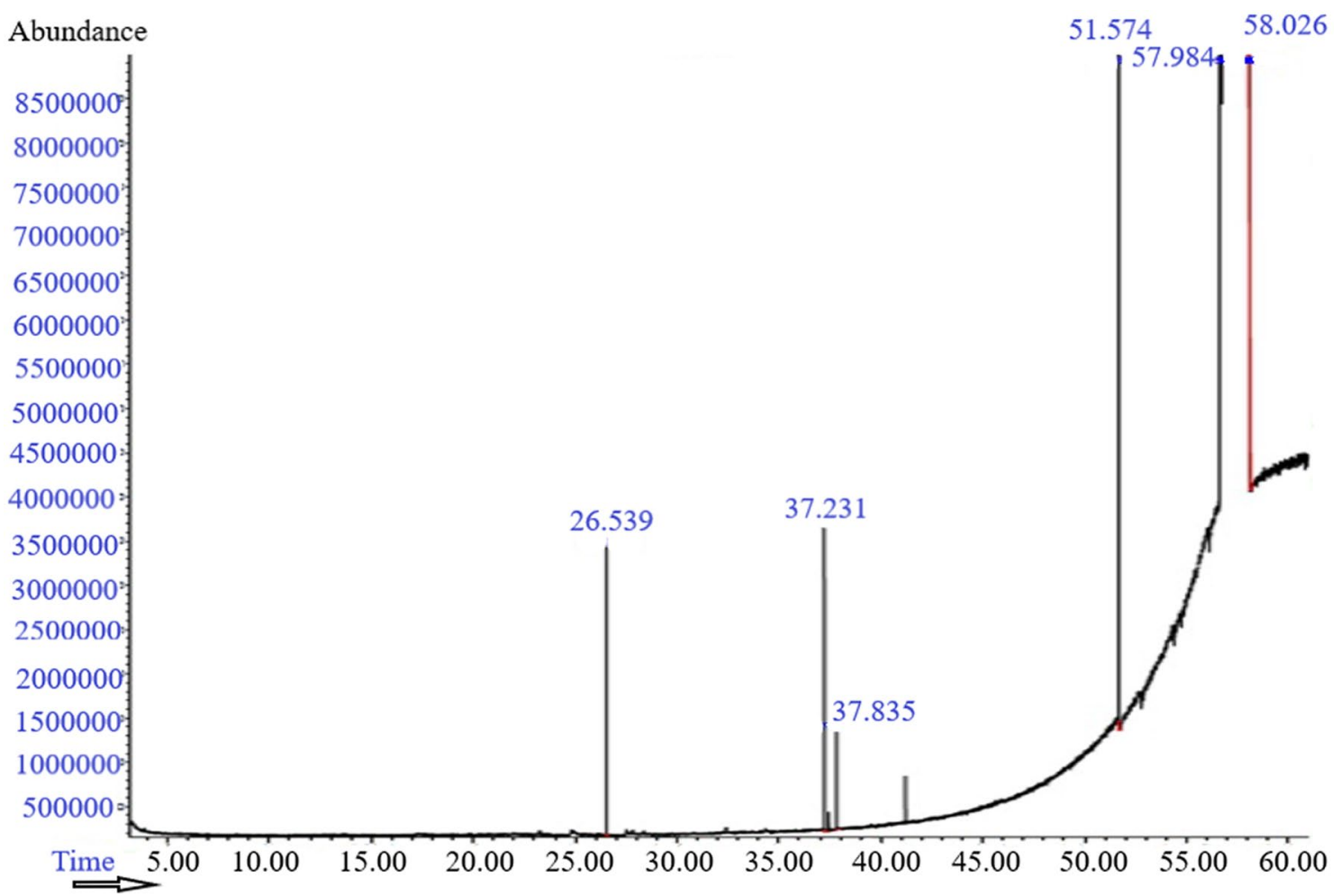

Fig. 6 Total ionic chromatogram biological active compound of methanol extract of Oscillatoria sp. with HP-5 column ( $30 \mathrm{~m} \times 0.25 \mathrm{~mm})$ with helium as carrier gas

Table 2 Total ionic chromatogram biological active compound of methanol extract of Oscillatoria sp. with HP-5 column ( $30 \times 0.25 \mathrm{~mm}$ ) with helium as carrier gas

\begin{tabular}{llll}
\hline Compounds name & Compound nature & Molecular formula & $\begin{array}{l}\text { Retention } \\
\text { time (min) }\end{array}$ \\
\hline 4,6-bis(diethylamino)-1,3,5-triazine & Triazine derivative & $\mathrm{C}_{3} \mathrm{H}_{3} \mathrm{~N}_{3}$ & 26.544 \\
5-Nitro-3-cyano-2(1H)-pyridone & Pyridone derivative & $\mathrm{C}_{5} \mathrm{H}_{4} \mathrm{NH}(\mathrm{O})$ & 32.401 \\
Triphenylphosphine oxide & Phenyl derivative & $\mathrm{C}_{18} \mathrm{H}_{15} \mathrm{OP}$ & 40.946 \\
1,4 benzenedicarboxamide & Phathalic acid derivative & $\mathrm{C}_{6} \mathrm{H}_{4}(\mathrm{COOH})_{2}$ & 47.525 \\
Benzenemethanol & Benzyl alcohol derivative & $\mathrm{C}_{7} \mathrm{H}_{8} \mathrm{O}$ & 49.460 \\
trimethylsilyl ether & Ether derivative & $\mathrm{C}_{5} \mathrm{H}_{12} \mathrm{OSi}_{1}$ & 49.927 \\
2-Methyl-7-phenyl indole & Indole derivative & $\mathrm{C}_{8} \mathrm{H}_{7} \mathrm{~N}$ & 57.984 \\
Acetic acid & Fatty acid & $\mathrm{C}_{2} \mathrm{H}_{4} \mathrm{O}_{2}$ & 58.026 \\
Silicic acid & Carboxylic acid & $\mathrm{Si}_{(}\left(\mathrm{OH}_{4}\right.$ & 58.292 \\
9-Oxo-9,10-dihydro acridine-4-yl & Acridine derivative & $\mathrm{C}_{13} \mathrm{H}_{9} \mathrm{~N}$ & 59.823 \\
2-(p-Fluorophenyl)-6-methylcinchoninic acid & Cinchoninic acid & $\mathrm{C}_{10} \mathrm{H}_{7} \mathrm{NO}_{2}$ & 60.003 \\
5-Methyl-2-phenyl indolizine & Indolizine derivative & $\mathrm{C}_{15} \mathrm{H}_{13} \mathrm{~N}$ \\
\hline
\end{tabular}

The 1,3,5-triazine was the bioactive compound identified at retention time of $26.544 \mathrm{~min}$. Triazine was included in chemical species of heterocyclic aromatic ring compound where the three nitrogens replaced the carbonhydrogen units on the benzene ring. 1, 3, 5-triazine represent incredible class of compound with wide spectrum of biological activities such as antimicrobial, anticancer, antiviral and fungicidal $[38,39]$. The earlier report by Sarmah and Patel [40] also had reported that the triazine derivatives have potential against gram-positive bacteria such as B. subtilis and S. aureus and gram-negative bacteria such as P. aeruginosa and E. coli. 


\section{Conclusion}

The result obtained from this experiment clearly revealed that Oscillatoria sp. can play crucial roles as antibacterial agents because the extract from Oscillatoria sp. showed impressive result for zone of inhibition area against grampositive bacteria (S. aureus and B. subtilis) and gramnegative bacteria ( $E$. coli and $P$. aeruginosa). However, the methanolic extract of Oscillatoria sp. from this experiment proved to be more actively in inhibiting the growth of $S$. aureus for gram-positive whereas $P$. aeruginosa for gramnegative bacteria. The antibacterial activity from the same extract of Oscillatoria sp. are for several bioactive compounds which has also been reported in many studies such as fatty acid, triazine derivatives, pyridine derivatives, acridine derivatives and etc. which had proven to be very effective in playing their role as antibacterial. The minimal inhibitory concentration (MIC) value in gram-positive bacteria was $30 \mu \mathrm{g} / \mathrm{ml}$ whereas for gram-negative bacteria was $25 \mu \mathrm{g} / \mathrm{ml}$. Oscillatoria sp. extract depends on those concentrations to control the growth of bacteria because of the bioactive compounds which function as antibacterial agent active and high amount in those concentrations. Based on the experiment, marine cyanobacteria (Oscillatoria sp.) have proven their potential as antimicrobial, anticancer, antioxidant and antitumor activity. The extract from cyanobacteria can be applied for various treatment for several diseases instead of using chemical drugs or treatments. Cyanobacteria extract should be preferred and considered to be new natural drug or antibiotics in pharmaceutical and health care industry. The authorities and responsibility should come out with new alternative in culturing microalgae in large scale for commercialization and improvement of the health care industry without side effects.

Acknowledgements The authors gratefully acknowledged Universiti Malaysia Pahang for the financial assistance through the Internal Research Grant No. RDU1903125 and Flagship Grant No. RDU182205. Author (Prakash Bhuyar) is thankful to UMP for providing Doctoral Research Scholarship DRS as a financial support.

\section{Compliance with ethical standards}

Conflict of interest There are no conflicts to declare.

\section{References}

1. Abad MJ, Bedoya LM, Bermejo P (2011) Marine compounds and their antimicrobial activities. Sci Against Microb Pathogon Communicat Curr Res Technol Adv 51:1293-1306

2. Bhuyar $P$, Rahim MHA, Yusoff MM, Maniam GP, Govindan N (2019) A selective microalgae strain for biodiesel production in relation to higher lipid profile. Maejo Int J Energy Environ Commun 1:8-14

3. Bhuyar P, Yusoff MM, Rahim MHA, Sundararaju S, Maniam GP, Govindan N (2020) Effect of plant hormones on the production of biomass and lipid extraction for biodiesel production from microalgae Chlorella sp. J Microbiol Biotechnol Food Sci 9:4. https://doi.org/10.15414/jmbfs.2020.9.4.671-674

4. Bhuyar P, Tamizi NABM, Rahim MHA, Maniam GP, Govindan N (2019) Effect of ultraviolet light on the degradation of lowdensity and high-density polyethylene characterized by the weight loss and FTIR. Maejo Int J Energy Environ Commun $1: 26-31$

5. Bhuyar P, Hong DD, Mandia E, Rahim MHA, Maniam GP, Govindan N (2019) Desalination of polymer and chemical industrial wastewater by using green photosynthetic microalgae, Chlorella sp. Maejo Int J Energy Environ Commun 1:9-19

6. Pramanik A, Mukherjee J (2011) Cyanobacteria from Indian sundarbans as a source of antimicrobial compounds. Int Conf Biosci Biochem Bioinform IPCBEE 5:23-26

7. Bhuyar P, Rahim MHA, Sundararaju S, Ramaraj R, Maniam GP, Govindan N (2020) Synthesis of silver nanoparticles using marine macroalgae Padina sp. and its antibacterial activity towards pathogenic bacteria. Beni-Suef Univ J Basic Appl Sci 9(1):1-15. https://doi.org/10.1186/s43088-019-0031-y

8. Saengsawang B, Bhuyar P, Manmai N, Ponnusamy VK, Ramaraja $\mathrm{R}$, Unpaprom $\mathrm{Y}$ (2020) The optimization of oil extraction from macroalgae, Rhizoclonium sp. by chemical methods for efficient conversion into biodiesel. Fuel 274:117841. https://doi. org/10.1016/j.fuel.2020.117841

9. Bhuyar P, Rahim MHA, Sundararaju S, Maniam GP, Govindan N (2020) Antioxidant and antibacterial activity of red seaweed Kappaphycus alvarezii against pathogenic bacteria. Glob J Environ Sci Manag. https://doi.org/10.22034/gjesm.2020.01.0

10. Bhagavathy S, Sumathi P, Jancy Sherene Bell I (2011) Green algae Chlorococcum humicola: a new source of bioactive compounds with antimicrobial activity. Asian Pac J Trop Biomed. https://doi.org/10.1016/S2221-1691(11)60111-1

11. Muthusamy G, Thangasamy S, Raja M et al (2017) Biosynthesis of silver nanoparticles from Spirulina microalgae and its antibacterial activity. Environ Sci Pollut Res 24:19459-19464. https://doi.org/10.1007/s11356-017-9772-0

12. Bhuyar P, Sathyavathi S, Math RK (2020) Production of bioethanol from starchy tuber (Amorphophallus commutatus) and antimicrobial activity study of its extracts. Afr J Biol Sci 2:7076. https://doi.org/10.33472/AFJBS.2.2.2020.70-76

13. Sundar L, Chang FN (1993) Antimicrobial activity and biosynthesis of indole antibiotics produced by Xenorhabdus nematophilus. J Gen Microbiol 139:3139-3148. https://doi. org/10.1099/00221287-139-12-3139

14. Selim SA (2012) Antimicrobial, antiplasmid and cytotoxicity potentials of marine algae Halimeda opuntia and Sarconema filiforme collected from Red Sea Coast. Int J Mar Environ Sci 6:24-29. https://doi.org/10.5281/zenodo.1072925

15. Vijayabaskar P, Shiyamala V (2011) Antibacterial activities of brown marine algae (Sargassum wightii and Turbinaria ornata) from the Gulf of Mannar Biosphere Reserve. Adv Biol Res 5:99-102

16. Sakthivel K, Kathiresan K (2012) Antimicrobial activities of marine cyanobacteria isolated from mangrove environment of South East coast of India. J Nat Prod 5:147-156

17. Bhuyar P, Sundararaju S, Rahim MHA, Ramaraj R, Maniam GP, Govindan N (2019) Microalgae cultivation using palm oil mill effluent as growth medium for lipid production with the effect of $\mathrm{CO}_{2}$ supply and light intensity. Biomass Convers Biorefinery 1-9. https://doi.org/10.1007/s13399-019-00548-5 
18. Vlachos V, Critchley AT, Von Holy A (1996) Establishment of a protocol for testing antimicrobial activity in Southern African macroalgae. Microbios 88:115-123

19. Ramli ANM, Manap NWA, Bhuyar P, Azelee NIW (2020) Passion fruit (Passiflora edulis) peel powder extract and its application towards antibacterial and antioxidant activity on the preserved meat products. SN Appl Sci 2:1748. https://doi.org/10.1007/ s42452-020-03550-z

20. Kolanjinathan K, Ganesh P, Govindarajan M (2009) Antibacterial activity of ethanol extracts of seaweeds against fish bacterial pathogens. Eur Rev Med Pharmacol Sci 13(3):173-177

21. Srinivasan $D$, Nathan $S$, Suresh $T$, Lakshmana Perumalsamy $P$ (2001) Antimicrobial activity of certain Indian medicinal plants used in folkloric medicine. J Ethnopharmacol 74:217-220. https ://doi.org/10.1016/S0378-8741(00)00345-7

22. Thillairajasekar K, Duraipandiyan V, Perumal P, Ignacimuthu S (2009) Antimicrobial activity of Trichodesmium erythraeum (Ehr) (microalga) from South East coast of Tamil Nadu, India. Int J Integr Biol 5:167-170

23. Vijayakumar A, Duraipandiyan V, Jeyaraj B et al (2012) Phytochemical analysis and in vitro antimicrobial activity of Illicium griffithii Hook. f. \& Thoms extracts. Asian Pacific J Trop Dis 2:190199. https://doi.org/10.1016/S2222-1808(12)60045-0

24. Cordeiro RA, Gomes VM, Carvalho AFU, Melo VMM (2006) Effect of proteins from the red seaweed Hypnea musciformis (Wulfen) lamouroux on the growth of human pathogen yeasts. Braz Arch Biol Technol 49:915-921. https://doi.org/10.1590/S1516-89132 006000700008

25. Manilal A, Sujith S, Selvin J et al (2009) Antibacterial activity of Falkenbergia hillebrandii (Born) from the Indian coast against human pathogens. Phyton 78:161-166

26. Khammee $P$, Ramaraj $R$, Whangchai $N$ et al (2020) The immobilization of yeast for fermentation of macroalgae Rhizoclonium sp. for efficient conversion into bioethanol. Biomass Convers Biorefinery. https://doi.org/10.1007/s13399-020-00786-y

27. Anandhan S (2011) Biorestraining potentials of marine macroalgae collected from Rameshwaram, Tamil nadu. J Res Biol 1:385-392

28. Salem WM (2011) Screening for antibacterial activities in some marine algae from the red sea (Hurghada, Egypt). Afr J Microbiol Res 5:2160-2167. https://doi.org/10.5897/ajmr11.390

29. Prakash JW, Johnson M, Jeeva S (2011) Antimicrobial activity of certain fresh water microalgae from Thamirabarani River, Tamil Nadu, South India. Asian Pac J Trop Biomed 1:S170-S173. https ://doi.org/10.1016/S2221-1691(11)60149-4
30. Rebecca LJ, Dhanalakshmi V, Shekhar C (2012) Antibacterial activity of Sargassum Ilicifolium and Kappaphycus alvarezii. J Chem Pharm Res 4(1):700-705

31. Bhuyar P, Zagade S, Revankar R, Yusoff MM, Rahim MHA, Govindan N (2018) Isolation, characterization and partial purification of keratinase from keratinolytic bacteria. Sch J Appl Sci Res 1:40-45

32. Kausalya M, Rao GMN (2015) Antimicrobial activity of marine algae. J Algal Biomass Util 6:78-87

33. Prabakaran P, Ravindran AD (2011) A comparative study on effective cell disruption methods for lipid extraction from microalgae. Lett Appl Microbiol 53:150-154. https://doi.org/10.1111/ j.1472-765X.2011.03082.x

34. Oh KB, Lee JH, Chung SC et al (2008) Antimicrobial activities of the bromophenols from the red alga Odonthalia corymbifera and some synthetic derivatives. Bioorganic Med Chem Lett 18:104-108. https://doi.org/10.1016/j.bmcl.2007.11.003

35. Bhuyar $\mathrm{P}$, Hong DD, Mandia E et al (2020) Salinity reduction from poly-chem-industrial wastewater by using microalgae (Chlorella sp.) collected from coastal region of peninsular Malaysia. J Bio Med Open Access 1(1):105

36. König GM, Wright AD (1997) Laurencia rigida: chemical investigations of its antifouling dichloromethane extract. J Nat Prod 60:967-970. https://doi.org/10.1021/np970181r

37. Vairappan CS, Suzuki M, Motomura T, Ichimura T (2001) Pathogenic bacteria associated with lesions and thallus bleaching symptoms in the Japanese kelp Laminaria religiosa Miyabe (Laminariales, Phaeophyceae). Hydrobiologia 445(1-3):183-191

38. Basedia KD, Dubey BK, Shrivastava B (2011) Review on synthesis and biological activity of lead moiety. Am J Pharm Tech Res 1:174-193

39. Ahmad MS, Cheng CK, Bhuyar P et al (2021) Effect of reaction conditions on the lifetime of SAPO-34 catalysts in methanol to olefins process: a review. Fuel. https://doi.org/10.1016/j. fuel.2020.118851

40. Sarmah KN, Sarmah NK (2014) Synthesis, characterization, antimicrobial studies of certain piperazine containing s-triazine derived compound. J Chem Pharm Res 6:127-132

Publisher's Note Springer Nature remains neutral with regard to jurisdictional claims in published maps and institutional affiliations. 